\title{
DE QUANTOS FIOS SE TECE UMA VIDA? \\ EXPERIÊNCIAS DE DOR, DO ABANDONO E DA ESPERANÇA
}

\author{
Maria Isabel Silva Bezerra Linhares ${ }^{1}$ \\ Nadja Rinelle Oliveira de Almeida ${ }^{2}$
}

\section{AS ARTESANIAS DAS PESSOAS EM SITUAÇÃO DE RUA NA "PRINCESINHA DO NORTE"}

\author{
Quem sou eu e quem é você \\ Nessa história eu não sei dizer... \\ De onde se vem pra onde vai... \\ Um dia a gente se encontra \\ Depois a gente se perde \\ No meu do mundo... \\ (Leo Jaime)
}

Damos início a tessitura deste texto, embaladas pelos trechos da letra de uma música escrita por Leo Jaime que expressa bem o mundo que as pessoas em situação de rua constroem e experienciam. Em seus mundos artesanais e imaginários são heróis que desenrolam uma vida marcada cotidianamente pela inconstância, pelos (des) encontros com a sua história e com os retalhos que restam dela.

Retalhos esses que compõem um imenso e não raro, dramático abismo que separa esse homem comum de sua história a partir desse cenário contemporâneo. Uma história em que ele é artífice em face da sociedade que o mobiliza, ao mesmo tempo como agente e ator se desenrolando como vida e teatro, como ação e fingimento. Um homem de diferentes modos e com diferentes intensidades, ao mesmo tempo ativo e impotente nas muitas caras que deve ter em meio a sua (in) visibilidade. (Martins, 2008).

Seus rendilhados podem ser simbolizados nas arquiteturas artesanais construídas com as suas mãos. Rendas tecidas com fios compostos de resíduos sólidos catados pelas ruas e fios de vida tecidos na urdidura de suas experiências. (Pais, 2013).

\footnotetext{
${ }^{1}$ Universidade Estadual Vale do Acaraú, Brasil. Email: isabelblinhares@yahoo.com.br ORCID id : https://orcid.org/0000-0003-2337-9810

${ }^{2}$ Universidade Estadual Vale do Acaraú, Brasil. Email: nadjarinelle_234@hotmail.com ORCID id: https://orcid.org/0000-0003-3094-3336
} 
Cidades de papelão ${ }^{3}$ que trazem os traços de seus nomadismos e nos fazem perceber suas fraturas com seus vínculos familiares e com as suas histórias.

Histórias líquidas que se espalham na cidade e a maculam, apesar da sua quase invisibilidade, não fosse tamanho o incômodo que provocam nas ruas da bela cidade de Sobral, no Ceará. Uma cidade que se desenha em um município reconhecido como Patrimônio Histórico Nacional pelo Instituto do Patrimônio Histórico e Artístico Nacional (IPHAN). Suas ruas, sobrados e igrejas fazem parte de um conjunto arquitetônico que se constitui de diversos momentos históricos que vai desde o colonial, no período de construção da cidade no final do século XVIII até meados do século XX, quando o ecletismo trouxe tendências arquitetônicas do art decó e art nouveau formando os bens patrimoniais tombados e preservados atualmente.

Nos entremeios desse conjunto belo de sobrados e igrejas, nomeada como Princesinha do Norte ${ }^{4}$ somos movidas a reconhecer um olhar para uma cidade invisível, que não se limita a quantos degraus são feitas às ruas em forma de escadas, da circunferência dos arcos. Como Calvino (1990) compreendemos que a cidade não é feita disso, das relações entre as medidas de seu espaço e os acontecimentos do passado, ela não conta o seu passado, ela o contém como as linhas da mão, escritas nos ângulos das ruas, nas grades das janelas, bem como nos vazios da noite que acolhem em seus becos, praças e viadutos, aqueles sem-teto, sem-família e desprovidos de toda sorte.

Haverá, certamente, muitas maneiras de abordar uma cidade, especialmente os fenômenos que a circundam. Pessoas tecem histórias na cidade, porque nela fixam suas raízes, se estabelecem. Como fixam raízes se a vida é recheada de armadilhas e muitas vezes alinhavadas nas incertezas do dia a dia? Quantos fios podem unir suas experiências de vida, se estes são tecidos na liquidez de sua existência?

\footnotetext{
${ }^{3}$ Categoria êmica pensada a partir da fala do entrevistado 2 quando diz: "Na rua eu não tenho casa para morar”. Entendemos que constroem suas cidades de papelão entre as arquiteturas da cidade de Sobral.

${ }^{4}$ Conhecida como a "Princesa do Norte", Sobral é a principal cidade da zona norte do Estado do Ceará e fica a $230 \mathrm{~km}$ de Fortaleza. Com uma população de 205.529 habitantes é o quinto município mais povoado do estado e o segundo maior do interior. possui uma taxa de urbanização de $88,35 \%$. Sobral é o segundo município mais desenvolvido do estado do Ceará, atrás apenas de Fortaleza, de acordo com o IDH (Índice de Desenvolvimento Humano). O seu patrimônio histórico constitui os principais pontos turísticos da cidade. Entre eles, destacam-se construções como o Museu Dom José de Sobral, o Arco de Nossa Senhora de Fátima, o Teatro São João, o Museu do Eclipse, a Casa de Cultura de Sobral, o Becco do Cotovelo e o Paço Municipal. O município também é destaque nas exportações, sendo o único município do interior que compete com a Capital a liderança nas exportações do Estado. A cidade de Sobral é considerada, de acordo com o IBGE, uma Capital Regional. Disponível em: https://pt.wikipedia.org/wiki/Sobral_(Cear\%C3\%A1). Acesso em: 18 abr. 2018.
} 
Observando os últimos acontecimentos da cidade de Sobral, no que diz respeito, especialmente, as decisões político-administrativas, procuramos entender como a nova ideia que movimenta a atual gestão pública da cidade - o "Ocupa Sobral", poderá recompor as fissuras da cidade, considerando as gritantes, porém (in)visíveis desigualdades entre seus habitantes. De início, lançamos as seguintes questões: A quem serve a cidade? Ou, quem dela se serve? Junto a estas questões, somaram-se nossas inquietações, sobretudo como abordar tal questão numa realidade que se apresenta com "opulência e tradição"

Como pesquisadoras da Universidade Estadual Vale do Acaraú (UVA), membros do Grupo de Estudos e Pesquisas sobre Culturas Juvenis (GEPECJU) e do Laboratório Trabalho, Educação, Gênero e Subjetividade (LATEGS), temos nos dedicado a orientar e supervisionar os Estágios em Movimentos Sociais e Educação Popular (MSEP) dos discentes do Curso de Pedagogia. Essas experiências nos têm levado a lugares diversos da realidade sobralense, nos aproximando sobremaneira de mundos sociais distintos e sem fronteiras.

Foi assim que nos deparamos com situações diversas e, neste caso específico, nossas ações político-profissionais nos aproximaram da realidade de pessoas que vivem as ruas, moram nelas e nelas constroem sociabilidades. Não nos aproximamos da vida destas pessoas especificamente como um objeto para a realização de estudos, com pretensões de definições generalizantes sobre as pessoas em situação de rua. Predefinir os modos de vida de cada uma destas pessoas como algo comum, vazio e sem histórias, implicaria não poder pensar fora dos limites dessa definição singularizante.

Interessamo-nos, portanto por apreender os significados da vida das pessoas em situação de rua em suas múltiplas manifestações, como ela se desenrola no seu cotidiano, buscando conhecer os fios que unem suas histórias de vida, cada uma marcada pelos percalços de sua existência. Vale ressaltar, que tal pretensão não significa fazer uma cartografia complexa e diversa dos modos de vida daquelas pessoas, mas de enxergá-las nas suas (in) visibilidades nos espaços públicos da cidade de Sobral, de

\footnotetext{
${ }^{5}$ Para o atual Prefeito de Sobral, Ivo Gomes, a expressão "Ocupa Sobral", que é a marca de sua gestão, não é só uma frase de efeito. Em seu pronunciamento oficial, durante seus primeiros dias na gestão municipal, assim falou: "Nós vamos ocupar mesmo a cidade. As praças, os espaços públicos, queremos as pessoas nas ruas vivendo a cidade".

6 Ver estudos de Nilson Almino de Freitas, cujo livro leva esse título: "Sobral: opulência e tradição" (2000).
} 
ouvi-las a partir dos seus silêncios abafados na bela cidade, mas que ecoam a partir de suas expressões e manifestações no centro da cidade.

Pais (2006), cita Blumer (1954), ao se referir à natureza dos registros empíricos observáveis, ao afirmar que

[...] o mundo empírico que a sociologia estuda é o mundo social da experiência quotidiana. Neste mundo, cada objeto que tomamos em consideração possui um caráter distintivo, único e peculiar, para além de se situar num contexto de caráter igualmente distintivo. (Pais, 2006: 27-28).

Embora os percursos de desvinculação social que conduzem a rua decorram de múltiplas vulnerabilidades, aqui nos concentramos, especialmente, no modo de vida que toma a rua como lugar quase exclusivo de existência. Entendemos que mesmo no espaço homogeneizador da rua, os trajetos das pessoas em situação de rua são múltiplos e variados, ainda que passíveis de alguma padronização. Portanto, dirigimos nosso olhar para as ruas, de modo especial, para lugares comuns por onde estas pessoas costumam ocupar. Aprendemos com Pais (2006: 47), que a circulação é uma imposição da própria geografia da rua, feita para circular. Mas quem vive na rua tem por hábito circular em espaços relativamente delimitados da cidade.

No espaço público das cidades também se constroem uma das formas mais radicais da chamada observação participante. Para Pais (2006: 21),

[...] O etnógrafo urbano é um participante natural da realidade que observa, ao permanecer oculto antes os olhares de quem observa. É um transeunte que se confunde com os demais. Ao participar num meio de estranhos, ser um estranho constitui-se em garantia máxima de discrição. Deste modo, o etnógrafo urbano está em condições de registrar, no terreno, uma realidade social fragmentada, cenário de transeuntes em trânsito que se encerram em sociabilidades anônimas, próprias de um estado de 'indiferença flutuante'. Essa é a estratégia do flâneur de Baudelaire: vê o mundo, está no mundo, mas permanece dele oculto. Estando dentro, mas também 'fora' do espaço de observação.

Portanto, o presente artigo é fruto das observações diretas nas ruas da cidade de Sobral, Ceará. Caminhos que construímos na nossa trajetória, como docentes, que vivem na cidade e pretendem interpretar seu modo de ser cidade princesa, com sua opulência e suas contradições. Ora caminhamos pelo seu avesso, outras, pelo lado que mais dela exploram: seu centro histórico. Caminhamos, por vezes, na clandestinidade, remirando "achados exóticos (comportamentais) para lhes achar os avessos endóticos (sociais)" (Pais, 2006: 21), misturando-nos com o público, incorporamos o papel de observador clandestino na nossa observação invisível. 
Passamos a estranhar nossa realidade cotidiana nos espaços públicos da cidade, ouvindo histórias dos deserdados de suas famílias, observando seus lugares de abrigo, conhecendo uma instituição que os acolhe, deixando-nos levar pelos sentidos, pelos odores, nas vias trajetivas dos contatos que estabelecemos. É nesse sentido que Pais (2006: 22) questiona as ciências sociais afirmando que elas

[...] exploram muito o 'objetivo' e o 'subjetivo', mas muito pouco o 'trajetivo' - feito de contatos, aproximações, trajetos, deambulações. $\mathrm{O}$ habitante comum da cidade gasta uma boa parte de seus esforços para não ver, não ouvir, não falar, não olhar, não tocar, com o objetivo de preservar o que ele pensa ser o seu espaço de intimidade e o dos outros.

Nosso olhar, ao percorrer a cidade, ouviu histórias silenciadas e agora transformam-se em escrita. Tomamos a narrativa como processo integrante da construção teórica e metodológica do nosso objeto de estudo, sobre as vidas das pessoas em situação de rua na cidade de Sobral. Vidas tecidas nas suas experiências de dor, de abandono, mas também de esperanças, por que têm esperanças e sonham.

A narração decorre do próprio processo de investigação, pois ao narrar as histórias de vida de algumas destas pessoas, procedemos a uma análise combinatória de observações dispersas, mas que ganham sentido no próprio processo descritivo, numa tentativa de entrelaçar os fios que compõem suas experiências.

Além das nossas deambulações na cidade e na instituição de abrigo, entrevistamos seis (06) pessoas que atualmente mantêm vínculos com o Centro de Referência Especializado para População em Situação de Rua - Centro POP ${ }^{7}$.

Contamos com a colaboração de um grupo de discentes do Curso de Pedagogia da Universidade Estadual Vale do Acaraú (UVA), em número de seis (06), as quais realizaram estágio na referida instituição. Orientamos o Estágio em Movimentos Sociais e Educação Popular, do curso de Pedagogia da referida Universidade. Também contamos com a colaboração de uma Pedagoga, que também realizou seu estágio, no ano de 2016, no referido Centro POP.

7 É o equipamento da Proteção Social Especial responsável pelo acompanhamento de pessoas em situação de rua. O equipamento oferta dois serviços: o Especializado para População em Situação de Rua e o Especializado em Abordagem Social. Oferece a esta população o acesso básico à alimentação, higienização e acompanhamento multiprofissional realizado por assistentes sociais, psicólogos, pedagogos (Especializado para PSR) e orientadores sociais (Abordagem Social). A equipe conta ainda com apoio de um assessor jurídico. (BRASIL, 2008). 
Ao recorrer a metodologia das entrevistas demos ênfase aos significados subjetivos dos relatos dos nossos interlocutores buscando entrelaçar os fios esgarçados de suas histórias e seus significados subjetivos, mesmo nos questionando se poderíamos chegar as suas experiências vividas, quando elas nos são dadas em palavras. Destacamos trechos de suas falas buscando suas significâncias, para mostrar que não podemos privá-los dos sentidos que dão as suas vidas. Destacamos o que é comum a essas pessoas, sem desconsiderar o que as distingue. São os diferentes modos de vivenciar a rua e enfrentar seus destinos, nas suas diversas expressões e manifestações, que nos permitiram alcançar o que há de comum entre elas.

\section{FIOS DE DOR E ABANDONO: A VIDA COMO ELA É...TECIDA NA EXPERIÊNCIA DE CADA DIA}

Rapaz, do tempo que eu saí de casa eu sempre fico ali na igreja São Francisco, debaixo do viaduto, dorme eu e bem uns cinco. Tem gente que hoje em dia tem bom coração, né, sempre ajuda a gente. Lá eles levam merenda, leva almoço, leva janta. A gente ganha um bocado de coisa lá. Tem gente que dá roupa pra gente lá. A gente vai vivendo o dia-a-dia. (Entrevistado 1).

A epígrafe acima é o trecho da fala de uma pessoa em situação de rua, que participava das atividades do Centro POP, quando acompanhávamos as atividades de uma de nossas alunas do Estágio Supervisionado em Movimentos Sociais e Educação Popular, no ano de 2016. O Centro POP de Sobral atende atualmente 109 pessoas. Destas, 90\% são usuários de drogas. Muitos vivem apenas com ajudas e doações ou de trabalhos autônomos (flanelinhas). Durante a pesquisa verificamos também que pouco mais da metade (51\%) tem algum parente que reside na cidade, porém, a maioria não possui contato com estes, devido a conflitos familiares.

Olhando o cenário brasileiro e, de modo particular, a realidade sobralense, percebemos que essa situação deixou de ser um fato isolado, constituindo-se como fenômeno que tem relação estreita com a mendicância, indigência e a degradação humana. Além dos mendigos, surgiram nesses grupos outros personagens, que aí chegaram por razões diversas, sendo a condição de exclusão social o elo que os une. (Silva, 2008).

Nas trilhas do nosso olhar trajetivo, na realidade sobralense, entendemos que há realidades sociais que nos dizem muito mais do que aquilo que sobre elas podemos imaginar. Os seus significantes excedem os significados. São realidades que envolvem 
vidas, a exemplo das pessoas em situação de rua, "dificilmente perturbam a paz ignorante dos donos de outras vidas que, sem saberem, nem sempre se furtam a uma existência supérflua" (Pais, 2006: 33). De um modo geral, estas pessoas dão corpo as representações sociais que retratam a realidade, ao mesmo tempo que a putrefatam, tornando-a corriqueira, banal e ignorada pela população. $\mathrm{Na}$ representação social dominante, estas pessoas tornam-se refém da miséria causada pela exploração capitalista, passando a condição de supérfluos, sobrantes.

Em suas análises no livro O Mal Estar da Pós Modernidade, Bauman (1998), recorre a metáfora do turista e do vagabundo, alertando que turistas e vagabundos são as metáforas da vida contemporânea. Para Bauman (idem), os vagabundos são a caricatura que revela a fealdade escondida sob a beleza da maquiagem. Sua presença é enfadonha e enraivecedora. Não há nenhum proveito evidente que se lhes possa tirar: pelo que se sabe, pode-se dar-lhes destino sem nenhuma perda ou pena - nem mesmo deles próprios. Em decorrência destas análises, Bauman (idem) sugere que,

[...] em nossa sociedade pós-moderna, estamos todos - de uma forma ou de outra, no corpo ou no espírito, aqui e agora ou no futuro antecipado, de bom ou de mau grado - em movimento; nenhum de nós pode estar certo/a de que adquiriu o direito a algum lugar uma vez por todas, e ninguém acha que sua permanência num lugar, para sempre, é uma perspectiva provável. Onde quer que nos aconteça parado estamos, pelo menos, parcialmente deslocados ou fora do lugar. Mas aqui termina o que há de comum na nossa situação e começam as diferenças. (Bauman, 1998: 118)

As primeiras entrevistas, decorrentes da nossa observação direta, ocorreram no ano em referência e, inicialmente, lançávamos as seguintes perguntas: Como é o seu dia a dia na rua? O quê os levou sair de casa? Tanto o entrevistado 1, como o entrevistado 2, falaram dos motivos de sua saída de casa para as ruas, bem como sobre as suas experiências na rua. "É, aqui e acolá a gente ganha umas moedinhas pra comprar alguma merenda, um cigarro. Lá na Igreja tem a missa e a gente pastora carro lá. (Entrevistado 2). Abaixo, o entrevistado 1 relatou:

Tem um rapaz que tá mais eu também, só que ele é viciado em cachaça, né. Ele é pedreiro profissional, só que ele veio embora de casa pro meio da rua, assim, porque ele bebia muito, aí ele começou a brigar dentro de casa aí saiu pro meio da rua. Eu não, já sou o contrário, eu não minto pra ninguém não. Eu sou usuário de droga, eu uso craque[...] Eu tô no meio da rua, tô. Eu não culpo minha família pelos meus erros, né. Porque o errado fui eu[...] Daí, eu tava conversando com um irmãozinho que mora lá pertinho, perguntou se eu pretendo passar o resto da minha vida no meio da rua. Rapaz, eu num pretendo não. Porque antes deu usar essas drogas eu era um cara trabalhador[...] eu tô determinado. Eu já fui pra fora de casa umas três vezes através dessas drogas. (Entrevistado 1). 
Entre os chamados pessoas em situação de rua, ou os vagabundos, os moradores de rua, os flanelinhas, entre outras denominações, encontramos histórias de vida distintas ainda que, por condições diversas todos passam a ter por leito um pedaço de rua - em Sobral: o viaduto da Igreja São Francisco, o espaço lateral do Banco do Nordeste, a Praça de Cuba, o largo da Igreja do Rosário, O Museu Madi entre outros -, e pela força desses encontros forjados pelas suas desventuras, passam a partilhar das mais diversas formas de desenlaces sociais. É o que podemos perceber nos seus relatos, principalmente quando falam da experiência desafiadora de viver na rua. $\mathrm{O}$ entrevistado 2 menciona esses desafios: "O desafio é fome, necessidade, banho e outros desafios pelo perigo da vida, né? [...] Risco de se morrer. Eu também já fui furado na rua, já fui operado[...]. (Entrevistado 2). Já os entrevistados 3 e 5 se referem a esses desafios:

\begin{abstract}
Morar na rua é tipo, a pessoa tá dormindo a noite chega um mal elemento pra fazer o mal com a pessoa, sempre acontece, sempre aparece um indivíduo ruim, pra furar, tocar fogo nos outros. Tem um que tava dormindo lá mais a gente chegou um cara tacou a faca nele, levaram ele pro hospital. (Entrevistado 3).

É[...] sol, cansaço, noite mal passada, você não pode dormir, você não dorme, usuário de rua não dorme, cochila[...]Não é um cochilo que você apaga ali uns dez, vinte minutos, meia hora, no máximo duas horas, com a mente aberta. O que funciona no ser humano é a mente, você não pode deixar a mente fechada, como você fecha uma porta dessa aí e vai dormir, você apaga. Ali o corpo relaxa por completo, a mente apaga outra coisa. No meio da rua, não. Mesmo que você esteja com os olhos fechados, boca fechada, mas os ouvidos têm que ficar na alerta. A mente tem que funcionar, mesmo que você ressona, você tá ressonando com a mente funcionando, uma transvalia que você passa no corpo. Todos eles só dormem se for bebo ou drogado, muito drogado que não tenha capacidade nem de respirar. Ele apagou. Uma noite na minha cama, eu cansei de ver pessoas passar aqui e eu, aqui com a coberta, eu vi pessoas paradas ao meu lado e eu só fazia assim de uma vez: pode dizer que você aceito, que vocês querem, vocês querem fumar um cigarrinho? As vezes malandro tirava um cigarro, acendia. Taí, vaza que aqui só dá pra um. (Entrevistado 5).
\end{abstract}

Das conversas que tivemos com eles, nos demos conta que, mais do que as desvinculações do mundo do trabalho, as rupturas afetivas foram determinantes na opção de viver na rua. Tais desvinculações são decorrentes do esgarçamento dos laços familiares, das uniões conjugais ou dos diversos relacionamentos que construíram ao longo de suas vidas.

Nas várias situações citadas durante as entrevistas, percebe-se que falham as redes de apoio familiar em momentos críticos da vida. Permanecem as lembranças, por vezes silenciadas pelas circunstâncias desafiadoras da sobrevivência. Para nós, ficou a impressão de que restam fios de esperanças, mesmo que muitos deles sejam “moribundos cuja vida é uma clara sobrevivência de uma insuspeita 'morte social' - 
estado de alienação, de afastamento das redes sociais de parentesco em ambos os sentidos genealógicos (ascendente e descendente)". (Pais, 2006: 47).

\section{FIOS DE ESPERANÇAS: QUEM VIVE NAS RUAS PODE SONHAR E ESPERANÇAR?}

Este novelo que reconhecemos nesse texto como esperançar ${ }^{8}$ é um dos fios que escolhemos para tecer algumas artesanias a partir desses nômades que percorrem pelas ruas de Sobral. Realizar essas tessituras é nos sentirmos como um poeta, na visão de Manoel de Barros, que tenta desexplicar algo que já está posto na Política Nacional de Inclusão Social (Brasil, 2008), ao considerar esse grupo populacional vinculado à pobreza, ao rompimento dos vínculos familiares. São sujeitos desfiliados socialmente pela ausência de um trabalho assalariado e não possuem uma moradia regular e convencional.

Nos reportamos a um desexplicar, porque nesse cenário composto por homens comuns $^{9}$ que fazem do meio do mundo ${ }^{10}$ sua moradia, nos debruçaremos na tentativa de ir ao encontro dos sonhos desses sujeitos, mesmo que seus corpos ocupem o cenário das ruas ao construírem cidades de papelão instaladas nos becos, nos sobrados, nos viadutos, nas calçadas, nas praças com as linhas das suas mãos (Calvino, 1990) para sobreviverem.

Linhas essas que sinalizam um cotidiano sombrio marcado pela negação de si mesmo e de sua dignidade humana pelos nós que foram/são rompidos. Ao fazer uma reflexão sobre o ser humano, Boff (2000) mostra-o como um nó de relações, um ser de abertura, concreto, mas aberto, voltado em todas direções.

Esses homens comuns do meio do mundo nos conduzem a enxergar uma cidade que é edificada de pedra e carne, com investimentos humanos materiais, simbólicos, imaginários (Argan, 1998). Uma cidade dos homens composta por corpos que se sentem (in) visíveis no meio social, mas percebem-se como paredes de carne de uma arquitetura

\footnotetext{
8 Ao nos reportarmos a palavra esperançar estamos nos alinhando a uma perspectiva freiriana, ao reconhecer que somos seres transformadores da própria realidade, mediatizados pelo mundo que olhamos, tocamos, sonhamos, transmutamos. No decorrer do texto faremos o devido aprofundamento.

${ }^{9}$ Usaremos no decorrer desta sessão a expressão homem/homens comuns a partir de Martins (2008).

${ }^{10}$ Categoria êmica pensada a partir da fala do entrevistado 1 ao se referir a sua moradia na rua como o meio do mundo.
} 
qualquer como pronuncia o entrevistado 1: "Tem gente que passa assim pela pessoa e finge que a gente é uma parede dessa aqui, não está nem aí, não!"’. (Entrevistado 1).

Pousar o olhar sobre essa complexa teia de significações que as ruas se anunciam na vida desses homens comuns é refletir sobre uma história social marcada pelos preâmbulos experienciados na cena cotidiana e nos modos de vida provenientes dessas fraturas que resultam nas incertezas que compõe um cenário de exclusão social. Como Demo (2003) nos coloca, a exclusão social mais dramática não é só não dispor de bens essenciais. É sobretudo, não conseguir alçar-se à condição de sujeito capaz de comandar seu destino. Nega-se não só acesso material, mas principalmente a autonomia emancipatória.

A medida que fomos percorrendo pelas esferas da exclusão no encontro com esses sujeitos, nos deparamos com suas tranpolinagens ${ }^{11}$ e isso nos instigou a pensar: Que sujeitos são esses que constroem suas táticas nas ruas da princesinha do norte? Que potências carregam de si para serem capazes de comandar o seu próprio destino? Que fios de esperança podem ser tecidos mesmo vivendo no meio do mundo?

A arte de saltar nos trampolins das ruas demanda desses corpos táticas que se fazem e se refazem cotidianamente. São espertezas, reconhecidas por Certeau (2013) no modo de utilizar os jogos impostos pelo outro. Nessa arte dos golpes, esses sujeitos criam seus dribles ao se colocarem diante de um sistema estabelecido para quem vive nas ruas. Um dos ocupantes da cidade de papelão expõe: "Cara tu vai morar aqui mais nós na rua, só não pode andar roubando, fazendo pirangagem com ninguém porque o cara está morando na rua e pode ser pego a traição quando tiver dormindo a qualquer momento". (Entrevistado 1).

Esses corpos instalados nas ruas constroem outros nós de relações para aos poucos desvendarem os códigos, as senhas e os pactos estabelecidos. Passam a fazer parte de uma cidade que até então não conheciam antes de se tornarem moradores dela. Uma cidade que não tem lugar fixo, mas possui suas regras e modos de funcionamento numa lógica promovida pelos movimentos da vida desses sujeitos.

O corpo -vitrine da cidade - ostenta e expressa, respectivamente, a exclusão e a dinâmica que os sujeitos da rua vão encenando ao se deslocarem de um lado para

11 Certeau (2013) se refere a um jogo de palavras associado a acrobacia do saltimbanco como trapaçaria, astúcia e esperteza no modo de utilizar ou de driblar os termos dos contratos sociais. 
outro, pois, sendo nômades, exigência de quem mora nas ruas da cidade, nunca sabem se podem permanecer muito tempo em algum lugar. ${ }^{12}$ (Grifos nossos).

A cada deslocamento realizado por esse homem do meio do mundo se edifica uma cidade que contraria as normatizações impostas pelo espaço urbano. Uma cidade com seus truques significados pela esfera pública ${ }^{13}$ em atos de delinquência, entendidos por Certeau (2013) como códigos que desmancham e se deslocam, contrariando os usos normalizadores e padronizadores do espaço urbano.

A cidade posta por esses homens no espaço urbano é desenhada com os contornos de seus estilos de vida. Um corpo-cidade ${ }^{14}$ que tem suas resistências e disputas. Um espaço privado projetado nas arenas públicas do cenário urbano. Uma cidade personificada por esses habitantes, nos dizeres de Calvino (1990) ao se reportar as cidades invisíveis dotadas pelo corpo e não somente como monumento arquitetônico. Uma cidade vista sob o olhar do viajante como aquela que pulsa a partir das histórias dos corpos que se movimentam entre suas arquiteturas materiais e simbólicas.

Para Campos (2011) as cidades são, também lugares nodais para o desenvolvimento de culturas, no sentido antropológico do termo. Estas representam um espaço de diferenciação, de confrontos e de negociação entre desiguais comunidades e classes sociais. A alteridade está, portanto, mais presente, mas também mais evidente. $\mathrm{O}$ espaço público é uma arena por onde circulam diferentes gentes com referências culturais e sociais distintas.

É nessa conjuntura que vemos o corpo-cidade de quem está em situação de rua sendo formulado fora dos dispositivos de regulamentação de um território humano e material mercantilizado pela indústria cultural. O espaço urbano vai sendo ocupado com espaços de conhecimento e de lazer, oferecendo uma cultura elevada e erudita, porém, distante para esses agentes que ocupam o cenário da rua.

$\mathrm{Na}$ cidade de Sobral o consumo simbólico dessa indústria cultural costuma acontecer para essa camada da população ao utilizarem os logradouros públicos. O

\footnotetext{
12 Ver nas referências, Adad (2011).

13 O conceito de esfera pública no entendimento de Arendt (1987). Imposição de inúmeras e variadas regras, todas elas tendentes a normalizar os seus membros, abolindo a ação espontânea ou a reação inusitada.

${ }^{14}$ Expressão utilizada por Diógenes (2003) ao se reportar os trajetos dos corpos na cidade.
} 
Museu $\mathrm{Madi}^{15}$, por exemplo, é um desses locais onde esses corpos ocupam suas calçadas, transformando-as em cama e mesa para moradias temporárias.

Dialogando com Barthes (1987:187) percebemos que a cidade é um discurso, e esse discurso é verdadeiramente uma linguagem que fala aos seus habitantes. Para ele "nós falamos a nossa cidade, a cidade onde nós nos encontramos simplesmente quando a habitamos, a percorremos, a olhamos".

Olhar a cidade a partir das experiências de moradia nas ruas vividas por esses corpos diz muito sobre as ruas, as calçadas, as pedras, as performances corporais, as formas de uso, os mundos superpostos e linhas fronteiriças. (Diógenes, 2003). Anuncia as questões sociais mais amplas, as necessidades de efetivação de políticas públicas emancipatórias, os seus modos de vida, as estratégias de sobrevivência e o que se pode esperançar nesses corpos.

Esperançar nesses corpos-cidade espalhados pelo meio do mundo não é uma tarefa fácil. Os fios de esperança são esgarçados e/ou rompidos cotidianamente pelas trajetórias de exclusão social que costumam experienciar. Situações essas que não estão alicerçadas somente na ausência de moradia.

A fragilização dos laços familiares, de amizade, o rompimento com o mundo do trabalho, problemas de alcoolismo e/ou drogas são fios que manifestam um desesperançar na vida desses homens comuns, podendo, ao mesmo tempo, tecer artesanias de sonhos ao conseguirem emendar alguns desses fios, como ser incluído no mercado de trabalho, ter moradia e construir uma família.

Ao se falar de sonhos para um desses homens comuns ele questionou: "Meu sonho?! Rapaz, eu tenho sonhos sim! Quem que não tem sonhos, né?! E continua: "Eu pretendo trabalhar, ajudar minha família, construir uma família para mim também, né?!”. (Entrevistado 1). Complementamos com outro depoimento do entrevistado 2: "Meu sonho é ter uma casa para morar e parar de usar droga, né?! Quero só a minha saúde! Só tenho a roupa do meu corpo e nenhuma rede para dormir, então, eu sonho com uma moradia para dormir sossegado." (Entrevistado 2).

Não poderíamos discorrer sobre as tessituras desses fios de esperança sem nos remetermos a Freire (2011) quando ele tece suas considerações sobre essa palavra. Ele nos diz que somos seres inacabados e em constante transformação, de si e da realidade

15 Museu de Arte Contemporânea e Abstrata, único no Brasil, na cidade de Sobral inaugurado em julho de 2005. Disponível em: http://cultura.sobral.ce.gov.br/espaco/1223/. Acesso em: 10 mai. 2018. 
ao redor, encharcados de um esperançar que impulsa a sermos agentes transformadores da própria realidade, mediatizados pelo mundo que olhamos, tocamos, sonhamos, transmutamos.

No entanto, esses homens comuns, ao tentarem comandar seu próprio destino habitando suas cidades de papelão, vão perdendo o endereço da esperança em virtude das situações-limite geradas principalmente pela violência. São relações de poder que invadem a cena das ruas e tornam nebulosos os dias de quem tem moradia nela. Com isso, esses sujeitos passam a ter um olhar mais restrito sobre as possibilidades de superação a partir das suas trajetórias de vida na rua.

Tendo por base esse cenário, como destaca Martinez (2011), a noção de situação de rua pode ser revertida através da reinserção destes excluídos no mercado de trabalho. Se por um aspecto a situação de rua é definida por uma categoria de unidade (neste caso apresentado como o desempregado), por outro aspecto, a heterogeneidade destes atores são pensadas através do grau de vinculação com o mundo da rua.

Nesse mundo às avessas que podemos reconhecer como a rua, a esperança passa a pulsar nesses corpos ao perceberem nas linhas de suas mãos a possibilidade de mudança de um destino que contrarie as suas experiências cotidianas. Uma esperança que, ao ser guiada pelos sentidos, instiga a construção de sonhos onde suas bases nascem do desejo de libertar-se de um sistema de organização da sociedade que exclui, oprime.

Sair da rua, voltar para o convívio familiar e conseguir qualquer coisa para ganhar um trocado podem ser entendidos também como seus processos de resistência. O campo de resistência pensado na perspectiva de Deleuze (1992) nos leva a perceber que não cabe temer ou esperar, mas buscar novas armas. Resistir nesse caso ultrapassa o combate as normas impostas, a hegemonia de um sistema, mas a capacidade de reinventar-se na continuidade entre a vida antes e depois da rua.

Assim, diferentemente do que vemos, ouvimos, lemos e até discorremos para problematizar a possibilidade desses homens comuns de esperançarem diante do acúmulo de experiências vividas na rua, fica o questionamento: É possível tecer fios de esperança sendo um corpo-cidade que se move, interage, atua na rua cumprindo ou não funções, produto e produtor do contexto (Fraya, 2009)?

Desse modo, não é suficiente dizer apenas que esses homens comuns tecem artesanias de sonhos com seus fios de esperança. Fios que simbolizam o retorno as suas 
bases familiares, o resgate da dignidade ao conseguir um emprego retomando um passado que foi deixado para trás.

É justamente em suas trampolinagens nos usos da rua que encontramos um terreno complexo onde esse emaranhado de linhas tece uma realidade que eles precisam driblar, resistir e reinventar todos os dias ao estarem em suas cidades de papelão ou abandonando-as, pois, para construir suas pontes de futuro é preciso que se sintam capazes de fazerem suas próprias escolhas, expressarem suas convicções e se livrarem das (in) certezas, do risco que as ruas ofereciam/oferecem cotidianamente.

Libertar-se disso se torna o grande desafio desses homens comuns ao terem que construir ou retomar a confiança em si mesmos para se perceberem sentindo, vivenciando e experienciando esse esperançar. Um esperançar que pode conduzi-los a reconhecem suas capacidades diante de seus fazeres pela vida, como relata um desses homens: "Eu já trabalhei de servente, de pintor, eu faço de tudo, graças a Deus! De tudo um pouco eu sei fazer, Entendeu?!” (Entrevistado 1).

\section{QUEM SOU EU, QUEM É VOCÊ? TECENDO OS RENDILHADOS FINAIS}

Entendemos que o nosso maior desafio como pesquisadoras situadas num cenário tão diverso, mas que guarda nas representações dos que vivem a cidade de Sobral, dos seus turistas, como diria Bauman, seria desconstruir a ideia de uma cidade perfeita, pois ao se tornar Princesa, seus cidadãos úteis e produtivos ignorariam suas contradições.

Foi perceber que, ao olhar pela ótica da representação social dominante, os vagabundos, o refugo humano, pagam o justo preço pelo seu desajustamento ao mundo, por isso mesmo são olhados com desprezo e medo. Incorporam imagens de realidades construídas por um olhar que pouco ou nada vê em sua desatenção, ou que os transforma numa espécie de borradela na estética das cidades. (Pais, 2006).

Quanto as análises das entrevistas realizadas e as observações que planejamos num espaço trajetivo, podemos dizer sobre o estigma que ficou sobre as origens de todos aqueles (os que entrevistamos e acompanhamos e outros tantos que ocupam a cidade de Sobral), que desaguaram nas ruas e a tomaram como casa, espaço de dor e esperança, o que exige de nós ou outros/as pesquisadores/as um novo olhar sobre esta realidade. 
Das observações e entrevistas realizadas podemos concluir que as pessoas em situação de rua constituem uma população heterogênea, apesar de a "etiqueta" que lhes é dirigida - moradores de rua, vagabundos, flanelinhas, entre outros -, provoca uma homogeneização de diferenças dada por um denominador comum de necessidades e modos de ser.

Mesmo que todo estigma seja homogeneizador, essas diferenças não podem ser ignoradas. Uns habituaram-se a viver na rua, tomando-a como sua casa e espaço de sobrevivência, pois é onde conseguem alimentos, vestuários e fazem pequenos trabalhos, o que levam alguns a se autodenominarem de autônomos. Outros a consideram um lugar provisório e de improvisos, visto que alimentam esperanças de (re) encontro com seus familiares e com seu trabalho digno.

Esses fios de esperança significam para esses homens comuns uma artesania de sonhos que denotam em suas vidas possibilidades de transformação, pois, como seres inacabados, é sempre possível esperançar quando se ousa realizar novos percursos. Trajetivas que convidam ao (re) encontro com as suas histórias de vida antes de se tornarem moradores das cidades de papelão.

No entanto, realizar essas tessituras requer desses homens a coragem de abandonar os refugos que foram alojados em seus corpos durante o período que estiveram nas ruas. Para isso precisarão realizar suas trampolinagens para agora driblarem e resistirem a uma cidade em que eles estiveram excluídos por meses, anos. Enfrentar o desafio de ser incluído nela reconhecendo suas capacidades diante das novas rotas que terão que fazer em suas franjas.

\section{REFERÊNCIAS}

ADAD, Shara J. H. C. Corpos de Rua: cartografia dos saberes juvenis e o sociopoetizar dos desejos dos educadores. Fortaleza: Edições UFC, 2011.

ARENDT, Hannah. A Condição Humana. Rio de Janeiro: Editora Forense, 1987.

ARGAN, Giulio. História da Arte como história da cidade. São Paulo: Editora Martins Fontes, 1998. 
BAUMAN, Zygmunt. O mal-estar da pós-modernidade. Rio de Janeiro: Jorge Zahar, 1998.

BARTHES, Roland. A aventura semiológica. Lisboa: Edições 70, 1987.

BOFF, Leonardo. Tempo de transcendência. Rio de Janeiro: Editora Sextante, 2000.

BRASIL, Ministério do Desenvolvimento Social e Combate à Fome - MDS. Política Nacional de inclusão social da população em situação de rua. 2008, 25p.

CALVINO, Ítalo. As cidades invisíveis. São Paulo: Editora Companhia das Letras, 1990.

CAMPOS, Ricardo. Identidade, imagem e representação na metrópole. In: CAMPOS, Ricardo (Orgs)., et al. Uma cidade de imagens. Lisboa: Editora Mundos Sociais, 2011. p. $15-30$.

CERTEAU, Michel de. A invenção do cotidiano: 1. Artes de fazer. 20. ed. Tradução de Ephraim Ferreira Alves. Petrópolis, RJ: Editora Vozes, 2013.

DELEUZE, Gilles. Conversações. Rio de Janeiro: Edições 34, 1992.

DEMO, Pedro. Pobreza da pobreza. Petrópolis: Editora Vozes, 2003.

DIÓGENES, Glória. Linguagens de rebeldia: nomadismo juvenil na cidade. Revista de Educação, v. 32, n 127, abril/junho, 2003.

FRAYA, Frehse. "Usos da rua". In: FORTUNA, Carlos; LEITE, Rogério Proença. (Orgs.). Plural de cidade: novos léxicos urbanos. Coimbra: Editora CES/Almedina, 2009.

FREIRE, Paulo. Pedagogia da Esperança: um reencontro com a pedagogia do oprimido. 17. ed. São Paulo: Paz e Terra, 2011.

FREITAS, Nilson A. Sobral: opulência e tradição. Sobral-CE: Edições UVA, 2000.

MARTINEZ, Mariana M. Andando e parando pelos trechos: uma etnografia das trajetórias de rua. 2011. 166 p. Dissertação (Mestrado em Antropologia Social) Departamento de Ciências Sociais da Universidade Federal de São Carlos, São Carlos, 2011.

MARTINS, José de S. A aparição do demônio na fábrica: origens sociais do Eu dividido no subúrbio operário. São Paulo: Editora 34, 2008.

PAIS, José M. Nos rastos da solidão: deambulações sociológicas. Porto, Portugal: Editora Ambar, 2006.

PAIS, José M. O cotidiano e a prática artesanal da pesquisa. Revista Brasileira de Sociologia-SBS, v. 1, n 1, p. 107-128, jan/jul. 2013. 
SILVA, Rita de C. O. Superar no movimento: etnografia de performances de Pirráias em Recife e mais além. (Tese) Programa de pós-graduação em Antropologia Social. Universidade Federal de Santa Catarina, Centro de Ciências Humanas. Florianópolis, 2008. Disponível em: https://repositorio.ufsc.br/handle/123456789/91425. Acesso em: 11 abr. 2018.

Recebido: $31 / 05 / 2020$

Aprovado: 04/09/2020 